\title{
Dry Extract of Passiflora incarnata L. leaves as a Cardiac and Hepatic Oxidative Stress Protector in LDLr-/- Mice Fed High-Fat Diet
}

\author{
Danielle Aparecida Quintino Silva Sarto ${ }^{1 *}$, Ana Helena D'Arcadia de Siqueira ${ }^{2}$, Francisco \\ Monteiro de Almeida Magalhaes ${ }^{2}$, Karine de Paula Caproni ${ }^{1}$, Ângela Maria Martins ${ }^{1}$, \\ Gérsika Bitencourt Santos², Délcio Bueno da Silva ${ }^{3}$, Brígida Monteiro Vilas Boas ${ }^{1}$, José \\ Antônio Dias Garcia ${ }^{1,2}$ \\ ${ }^{I}$ Instituto Federal de Educação, Ciência e Tecnologia do Sul de Minas Gerais - Campus Machado, Machado, \\ Minas Gerais, Brasil; ${ }^{2}$ Universidade José do Rosário Vellano, Alfenas, Minas Gerais, Brasil; ${ }^{3}$ Instituto Federal de \\ Educação, Ciência e Tecnologia do Sul de Minas Gerais - Campus Muzambinho, Muzambinho, Minas Gerais, \\ Brasil.
}

\begin{abstract}
The control of dyslipidemia by using herbal products is an important subject for studies. In this study, we evaluated the effects of dry Passiflora incarnata L. extract over dyslipidemia, left ventricular hypertrophy, and hepatic oxidative stress of LDL receptor knockout mice (LDLr-/-). Forty 4-month old male LDLr-/- mice were distributed into four groups: Group standard diet; Group standard diet and $200 \mathrm{mg} / \mathrm{kg}$ of body weight of Passiflora incarnata L. leaf dry extract; Group high-fat diet; Group high-fat diet and $200 \mathrm{mg} / \mathrm{kg}$ of body weight of Passiflora incarnata L. leaf dry extract. After 30 days, Passiflora incarnata L. dry extract reduced the effects of the high-fat diet, with a decrease of total cholesterol, triglycerides, and increase of high-density lipoprotein (HDL), as well as a reduction of $C$-reactive protein, alkaline phosphatase and insulin. There was no effect on glucose, Homa index and enzymes aspartate aminotransferase and alanine aminotransferase. However, the prevention of left ventricular hypertrophy occurred, as well as lipid peroxidation and the production of carbonyl proteins, which are both oxidative stress markers. In conclusion, Passiflora incarnata L. dry extract acts in the prevention of dyslipidemia, consequently, hindering the occurrence of hepatic oxidative stress and the development of left ventricular hypertrophy by the increase of serum HDL, in mice that had the effects of a high-fat diet.
\end{abstract}

Keywords: Passion fruit; left ventricular hypertrophy; dyslipidemia; oxidative stress.

\footnotetext{
* Author for correspondence: danielleequintino@gmail.com
} 


\section{INTRODUCTION}

Dyslipidemia is one of the risk factors for the development of cardiovascular diseases ${ }^{1}$. The appearance of dyslipidemia derives from an abnormal lipid profile, composed of total cholesterol (TC), low-density lipoprotein (LDL), high-density lipoprotein (HDL) and triglycerides $(\mathrm{TG})^{2}$.

Dyslipidemia is also one of the biochemical factors for the development of left ventricular hypertrophy (LVH), as well as oxidative stress, hyperinsulinemia, and inflammatory process ${ }^{3,4}$. LVH is considered a highly relevant indicator of morbidity and mortality by cardiovascular diseases ${ }^{3}$.

Alterations on the serum concentration of cholesterol and triglycerides negatively act over the biomarkers of oxidative stress and cause the production of oxygen-reactive species by various mechanisms, leading to the increase of lipid peroxidation, related with dyslipidemia. Furthermore, the oxidative stress associated to dyslipidemia affects many organs, with prominence the over heart, liver, and kidneys ${ }^{5,6}$. Many hepatic diseases with structural and functional abnormalities have oxidative stress as a crucial factor for its development ${ }^{7}$.

Therefore, treating dyslipidemia is indispensable, preventing the emergence of LVH and hepatic diseases caused by oxidative stress. The change in habits is the primary strategy proposed for the treatment of dyslipidemia, but the use of medication is indicated for some cases ${ }^{8}$. Herbal medicines have been tested over changes of the lipid profile in the search for new treatments ${ }^{9,10}$, and have conquered the market due to its price and considering the collateral effects caused by medications ${ }^{9,11}$.

Passiflora incarnata L., also known as passion fruit, has been used as anxiolytic and sedative herbal medication. Many studies highlight its antispasmodic, analgesic, anticonvulsive and antidiabetic effect, as well as for a cough, bronchitis, and asthma $^{12,13}$. Flavonoids are the most representative phytocomponents of Passiflora incarnata L., represented by apigenin, luteolin, quercetin, kaempferol, C-glycosylated flavonoids, vitexin, isovitexin, orientin, isorientin, schaftoside, isoschaftoside, swertisin and isovitexin-2"-O-glycosylated ${ }^{14-16}$.

Therefore, considering the increase in research and the applicability of Passiflora incarnata L., the objective of this study was to evaluate the action of the dry Passiflora incarnata L. leaf extract over dyslipidemia, left ventricular hypertrophy and hepatic oxidative stress of LDLr-/- mice.

\section{MATERIALS AND METHODS}

\section{Animal protocol}

The experiments were conducted using 40 male mice, homozygote for the LDL receptor gene (LDLr-/-), with four months of age and weighing $25 \pm 3 \mathrm{~g}$, divided into groups of ten animals each (Table 1). The animals were maintained under controlled temperature $\left(25 \pm 1^{\circ} \mathrm{C}\right)$ and light/dark cycle of 12 hours. 
Table 1. Experimental groups and respective protocols.

\begin{tabular}{|c|c|c|}
\hline Group & Experimental protocol & Denomination \\
\hline 1 & $\begin{array}{l}\text { LDLr-/- mice that received a standard diet for rodents (Nuvital }{ }^{\mathrm{TM}} \text {, Nuvilab, Colombo, } \\
\text { Brazil), for } 30 \text { days. }\end{array}$ & $\mathrm{C}$ \\
\hline 2 & $\begin{array}{l}\text { LDLr-/- mice that received a standard diet for rodents (Nuvital }{ }^{\mathrm{TM}} \text {, Nuvilab, } \\
\text { Colombo, Brazil) and } 200 \mathrm{mg} / \mathrm{kg} \text { of body weight of dry Passiflora incarnata } \mathrm{L} \text {. } \\
\text { leaf extract per gavage, for } 30 \text { days. }\end{array}$ & $\mathrm{CP}$ \\
\hline 3 & $\begin{array}{l}\text { LDLr-/- mice that received high-fat diet with } 20 \% \text { total fat, } 1.25 \% \text { cholesterol and } \\
0.5 \% \text { colic acid; a total of } 2.89 \mathrm{kcal} / \mathrm{g} \text { (Instituto Tecnológico de Alimentos, } \\
\text { Campinas, Brazil), for } 30 \text { days. }\end{array}$ & HL \\
\hline 4 & $\begin{array}{l}\text { LDLr-/- mice that received high-fat diet with } 20 \% \text { total fat, } 1.25 \% \text { cholesterol and } \\
0.5 \% \text { colic acid; a total of } 2.89 \mathrm{kcal} / \mathrm{g} \text { (Instituto Tecnológico de Alimentos, } \\
\text { Campinas, Brazil) and treatment with } 200 \mathrm{mg} / \mathrm{kg} \text { of body weight of dry Passiflora } \\
\text { incarnata L. leaf extract per gavage, for } 30 \text { days. }\end{array}$ & HLP \\
\hline
\end{tabular}

All animals received water and food ad libitum. The administration of water (vehicle) and dry Passiflora incarnata L. leaf extract was performed daily by gavage. The extract was commercially obtained, containing $0.06 \%$ of total flavonoids calculated as vitexin (Gemini, Anapolis, Brazil). The experimental procedures were conducted according to directives established by the Concelho Nacional de Controle de Experiencias Animal (CONCEA - National Council for Animal Experience Control) and approved by the Animal Ethics Committee of the Universidade José do Rosário Vellano (UNIFENAS, Alfenas, MG, Brazil) (n $\left.{ }^{\circ} 12 \mathrm{~A} / 2012\right)$.

After 30 days of experimentation, mice were fasted for 12 hours and, subsequently anesthetized via intraperitoneal using xylazine $\left(\right.$ Bayer $^{\mathrm{TM}}$ ) and Ketamine (ParkeDavis $^{\mathrm{TM}}$ ), in the concentrations of 6 and $40 \mathrm{mg} / \mathrm{kg}$, respectively. Blood samples were collected by retro-orbital venous plexus puncture, using heparinized capillary tubes for serum analyses of triglycerides (TG), total cholesterol (TC), high-density lipoprotein (HDL), C-reactive protein (CRP), glucose, insulin and hepatic enzymes alkaline phosphatase (AP), aspartate aminotransferase (AST) and alanine aminotransferase (ALT). The heart was removed for following morphometric and histological analyses. The liver was removed and homogenized $\left(\right.$ at $\left.4^{\circ} \mathrm{C}\right)$ in buffer saline solution with $0.1 \mathrm{M}$ (PBS, pH 7.2) in the proportion of $5 \mathrm{~mL} / \mathrm{g}$ of the organ. The homogenized solution was centrifuged at $3000 \mathrm{~g}$ for 10 minutes at $4^{\circ} \mathrm{C}$. The supernatant was posteriorly used.

\section{Serum analyses}

Serum was obtained by centrifuging the blood $\left(1200 \mathrm{~g}, 4^{\circ} \mathrm{C}, 10\right.$ minutes $) . \mathrm{TG}, \mathrm{TC}$, and HDLc were measured using the colorimetric enzymatic methods, described by Hedrick et al. ${ }^{17}$.AP, AST, and ALT were dosed using spectrophotometry. The level of CRP was determined by turbidimetry and photometry (Humastar 300, Human Diagnostics, Germany). Glucose was measured by the colorimetric enzymatic method. Insulin was determined using the ELISA specific commercial kit (DAKO Ltd., UK). The Homa index (Homa-ir) was calculated using the formula: $\{$ Homa-ir $=[$ fast insulinemia $(\mathrm{mU} / \mathrm{L}) \times$ fast glycemia $(\mathrm{mmol} / \mathrm{L})] / 22.5\}$ to determine resistance to insulin. 


\section{Morphometric and histological analyses}

The left ventricle was isolated from the heart and weighed $(\mathrm{mg})$. The index of left ventricular hypertrophy was calculated using the proportion of ventricle weight $(\mathrm{mg})$ by body weight $(\mathrm{g})$. The left ventricle was fixed in $10 \%$ formalin for 24 hours before inclusion into paraffin for histological cuts of four micrometers, according to Junqueira et al. ${ }^{18}$. The histological cuts were stained with picrosirius red and hematoxylin/eosin for quantitative analysis of collagen and for cardiomyocyte morphometry, respectively. The cuts stained with picrosirius red were analyzed with polarized light. Each micrography was analyzed using the LGMC-image software, version 1.0 , by which the fractional percentages of collagen related to the areas marked in red were acquired ${ }^{19}$. Four photomicrographs $(200 \mathrm{x})$ were obtained from the histological cuts stained with hematoxylin/eosin, using the same pre-fixed point on the transversal cuts of the ventricle of each mouse, using a digital camera coupled to the Leica IM50 program (version 1.20). The diameters of eight to 12 cardiomyocytes of each histological cut were measured, totalizing 12 cuts for each animal ${ }^{20}$. All histological analyses were conducted by a single examiner using the double-blind method.

\section{Hepatic lipid peroxidation evaluation}

The lipid peroxidation evaluation was performed by measuring the peroxidation products that react to the thiobarbituric acid (TBA) by testing the reactive species (TBARS), according to the methodology described by Winterbourn et al. ${ }^{21}$. Aliquots $(150 \mu \mathrm{L})$ of the homogenized liver were mixed with $1.22 \mathrm{M}$ of phosphoric acid (750 $\mu \mathrm{L})$, deionized water $(1350 \mu \mathrm{L})$ and TBA $(0.67 \%, 750 \mu \mathrm{L})$ and incubated. Subsequently, the mixture was boiled in water for one hour at $95^{\circ} \mathrm{C}$ and taken to cooling in an ice bath $\left(4^{\circ} \mathrm{C}\right)$. The solution was mixed with methanol $(1800 \mu \mathrm{L})$ and $\mathrm{NaOH} 1 \mathrm{M}(200 \mu \mathrm{L})$ and transferred to a cuvette. The estimated TBARS concentration was obtained using the standard curve of malonic dialdehyde (MDA, 1,1,3,3 tetraethoxypropane). To quantify the MDA/TBARS, a spectrofluorometric detector Varian Cary Eclipse $(\lambda$ excitation $=532 \mathrm{~nm}$; emission $\lambda=563 \mathrm{~nm}$ ) was used. The results were expressed in $\mu \mathrm{mol} \mathrm{MDA} / \mathrm{mol}$ of protein. Total protein concentration was determined using the Bradford method ${ }^{22}$.

\section{Determination of carbonyl proteins}

Carbonyl of oxidized proteins was estimated using 2,4-dinitrofenylhydrazin spectrophotometric assay, by reacting 2,4-dinitrofenylhydrazin with carbonyl proteins. The aliquots $(500 \mu \mathrm{L})$ of homogenized solution (liver) and a $10 \mu \mathrm{M}$ 2,4dinitrofenylhydrazin solution $(500 \mu \mathrm{L})$ were incubated during one hour with dripping trichloroacetic acid (TCA, 20\%) until complete precipitation. Subsequently, a solution of ethanol/ethyl acetate $(500 \mu \mathrm{L})$ was added to the resulting mixture and centrifuged (600 $g$ per 10 minutes). Finally, the sediment was dissolved in $1000 \mu \mathrm{L}$ of Guanidine $6 \mathrm{M}$, and absorbance was measured at $370 \mathrm{~nm}^{23}$. The results were expressed in carbonyl $\mathrm{nmol} / \mathrm{mg}$ of total protein. Total protein concentration was determined using the Bradford method ${ }^{22}$.

\section{Statistical analyses}

The data were expressed as a mean \pm mean standard error (MSE). The analysis of variance (ANOVA) was followed by the Tukey test to compare the means between the 
different groups. The differences were considered significant at $\mathrm{p}<0.05$. All statistical treatments were performed using the Graphpad Instat statistical software, version 3.05, for Windows (Graphpad Instat ${ }^{\mathrm{TM}}$, San Diego, CA, USA).

\section{RESULTS}

The mice from the HL group presented increased serum levels of TC and TG when compared to the mice receiving a standard diet (group C). Serum levels of HDLc decreased. The administration of dry Passiflora incarnata L. extract prevented the increase of TC and TG in group HLP when compared to group HL (Table 2). The dry extract also partially inhibited the decrease in the HDLc levels of HLP mice, when compared to group HL (Table 2).

Severe dyslipidemia observed in mice from the HL group generated an increase in lipid peroxidation and hepatic protein oxidation concerning the other studied groups (Table 3). The dry Passiflora incarnata L. extract prevented the rise in lipid peroxidation and, more prominently, hepatic protein oxidation for HLP mice, with distinguished results when compared to mice from groups $\mathrm{C}$ and $\mathrm{CP}$ (Table 3). When analyzing the enzymes AP, AST and ALT, an increase in the serum levels of all three enzymes was observed in HL mice when compared to the mice from group C. The use of dry extract partially prevented the serum increase of AP in HLP mice. However, the dry extract presented no effect over AP serum levels of CP mice. The dry extract also presented no interference over serum levels of AST and ALT of CP and HLP animals when compared to $\mathrm{C}$ and HL groups, respectively (Table 2).

Table 2. Serum levels of total cholesterol (TC), triglycerides (TG) and HDL cholesterol (HDLc); alkaline phosphatase (AP), aspartate aminotransferase (AST) and alanine aminotransferase (ALT); C-reactive protein (CRP), glucose and insulin; HOMA index (Homa-ir).

\begin{tabular}{lllll}
\hline Groups & $\mathbf{C}$ & $\mathbf{C P}$ & HL & HLP \\
\hline TC (mg/dL) & $254 \pm 8^{\mathrm{b}}$ & $132 \pm 4^{\mathrm{c}}$ & $758 \pm 17^{\mathrm{a}}$ & $229 \pm 12^{\mathrm{b}}$ \\
TG (mg/dL) & $138 \pm 5^{\mathrm{b}}$ & $103 \pm 6^{\mathrm{b}}$ & $246 \pm 13^{\mathrm{a}}$ & $118 \pm 13^{\mathrm{b}}$ \\
HDLc (mg/dL) & $64 \pm 3^{\mathrm{a}}$ & $72 \pm 4^{\mathrm{a}}$ & $26 \pm 2^{\mathrm{c}}$ & $45 \pm 2^{\mathrm{b}}$ \\
AP (U/L) & $116 \pm 6^{\mathrm{c}}$ & $116 \pm 3^{\mathrm{c}}$ & $178 \pm 10^{\mathrm{a}}$ & $146 \pm 7^{\mathrm{b}}$ \\
AST (U/L) & $139 \pm 5^{\mathrm{b}}$ & $161 \pm 6^{\mathrm{b}}$ & $249 \pm 12^{\mathrm{a}}$ & $262 \pm 15^{\mathrm{a}}$ \\
ALT (U/L) & $64 \pm 6^{\mathrm{b}}$ & $66 \pm 4^{\mathrm{b}}$ & $181 \pm 17^{\mathrm{a}}$ & $170 \pm 17^{\mathrm{a}}$ \\
CRP (mg/dL) & $6 \pm 0.4^{\mathrm{c}}$ & $5 \pm 0.6^{\mathrm{c}}$ & $14.8 \pm 0.8^{\mathrm{a}}$ & $9.8 \pm 1^{\mathrm{b}}$ \\
Glucose (mMol/L) & $5.6 \pm 0.2^{\mathrm{a}}$ & $5.7 \pm 0.1^{\mathrm{a}}$ & $5.8 \pm 0.3^{\mathrm{a}}$ & $5.6 \pm 0.1^{\mathrm{a}}$ \\
Insulin (mU/L) & $2.8 \pm 0.2^{\mathrm{c}}$ & $2.7 \pm 0.2^{\mathrm{c}}$ & $6.1 \pm 0.8^{\mathrm{a}}$ & $4.0 \pm 0.3^{\mathrm{b}}$ \\
Homa-ir & $0.7 \pm 0.06^{\mathrm{b}}$ & $0.7 \pm 0.05^{\mathrm{b}}$ & $1.6 \pm 0.08^{\mathrm{a}}$ & $1.0 \pm 0.6^{\mathrm{a}, \mathrm{b}}$ \\
\hline Th & & $0.7 \pm 0.05$
\end{tabular}

The values were expressed as mean \pm MSE. Distinct letters indicate significant difference between groups ( $<<0.05-$ Tukey Test). C - standard diet; CP - standard diet and dry Passiflora incarnata L. leaf extract; HL - high-fat diet; HLP - high-fat diet and dry Passiflora incarnata L. leaf extract.

The mice from group HL presented resistance to insulin, which was demonstrated by the increase of Homa index and serum levels of insulin, without altering serum glucose levels (Table 2). The dry Passiflora incarnata L. extract partially prevented resistance to insulin in HLP animals, avoiding the increase of serum insulin levels and, consequently, the rise of the Homa index (Table 2). The partial effect of the dry extract over insulin resistance observed in HLP mice was demonstrated by the difference in the insulin serum levels and Homa index regarding mice from groups $\mathrm{C}$ and CP (Table 2). 
Table 3. Effect of dry Passiflora incarnata L. extract over lipid peroxidation and liver protein oxidation in dyslipidemic mice.

\begin{tabular}{lllll}
\hline \multicolumn{1}{c}{ Groups } & C & CP & HL & HLP \\
\hline $\begin{array}{l}\text { Lipid peroxidation } \\
(\mu \mathrm{mol} \text { MDA/mol of protein) }\end{array}$ & $0.08 \pm 0.008^{\mathrm{b}}$ & $0.06 \pm 0.0004^{\mathrm{b}}$ & $0.11 \pm 0.012^{\mathrm{a}}$ & $0.03 \pm 0.002^{\mathrm{c}}$ \\
$\begin{array}{l}\text { Protein oxidation } \\
\text { (nmol carbonyl/mg of total protein) }\end{array}$ & $2.84 \pm 0.67^{\mathrm{b}}$ & $2.63 \pm 0.37^{\mathrm{b}}$ & $5.47 \pm 0.67^{\mathrm{a}}$ & $2.44 \pm 0.79^{\mathrm{b}}$ \\
\hline
\end{tabular}

The values were expressed as mean \pm MSE. Distinct letters indicate significant difference between groups ( $\mathrm{p}<0.05-$ Tukey Test). $\mathrm{C}$ - standard diet; CP - standard diet and dry Passiflora incarnata L. leaf extract; HL - high-fat diet; HLP - high-fat diet and dry Passiflora incarnata L. leaf extract.

Severe dyslipidemia associated with the increase in hepatic oxidative stress and resistance to insulin of mice from group HL was followed by left ventricular hypertrophy, observed in the rise in the proportion of left ventricle weight (mg)/animal weight $(\mathrm{g})$ due to the increase in the diameter of the cardiomyocytes and collagen deposits in the left ventricular myocardium (Table 3, Table 4 and Fig. 1). The serum levels of CRP also increased for mice from the HLP group when compared to the other groups (Table 2). The dry extract prevented left ventricular hypertrophy and the increase of CRP for HLP mice (Table 4, Fig. 1 and Table 2).

Table 4. Morphometric parameters of the heart of dyslipidemic mice.

\begin{tabular}{lllll}
\hline \multicolumn{1}{c}{ Groups } & C & CP & HL & HLP \\
\hline Proportion ventricular weight $(\mathrm{mg}) /$ animal weight $(\mathrm{g})$ & $3.6 \pm 0.08^{\mathrm{b}}$ & $3.6 \pm 0.11^{\mathrm{b}}$ & $4.2 \pm 0.12^{\mathrm{a}}$ & $3.4 \pm 0.14^{\mathrm{b}}$ \\
Cardiomyocyte diameter $(\mathrm{mm})$ & $18 \pm 0.8^{\mathrm{b}}$ & $18 \pm 0.5^{\mathrm{b}}$ & $25 \pm 1.6^{\mathrm{a}}$ & $19 \pm 1.0^{\mathrm{b}}$ \\
Collagen deposits $(\%)$ & $4.9 \pm 0.2^{\mathrm{b}}$ & $5.1 \pm 1^{\mathrm{b}}$ & $11.2 \pm 0.8^{\mathrm{a}}$ & $4.6 \pm 0.9^{\mathrm{b}}$ \\
\hline
\end{tabular}

The values were expressed as mean \pm MSE. Distinct letters indicate significant difference between groups ( $\mathrm{p}<0.05-$ Tukey Test). $\mathrm{C}$ - standard diet; CP - standard diet and dry Passiflora incarnata L. leaf extract; HL - high-fat diet; HLP - high-fat diet and dry Passiflora incarnata L. leaf extract.

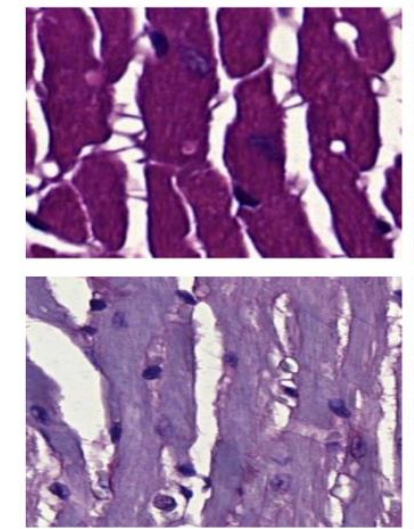

C
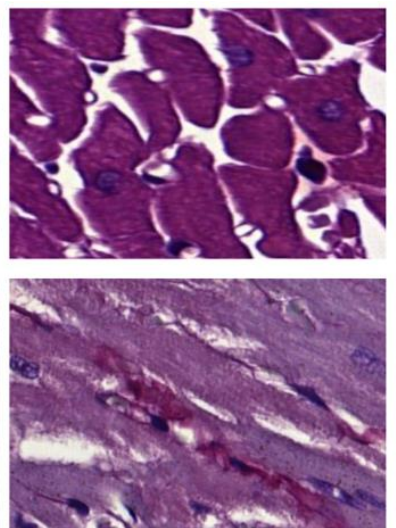

CP

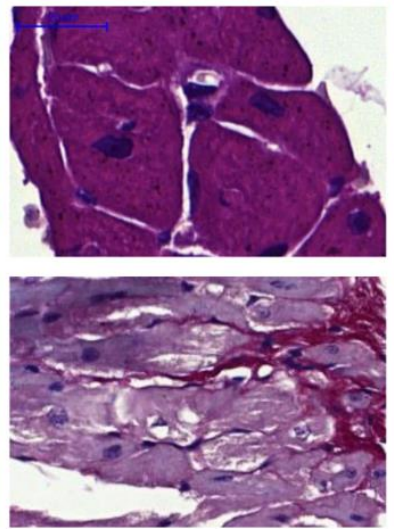

HL

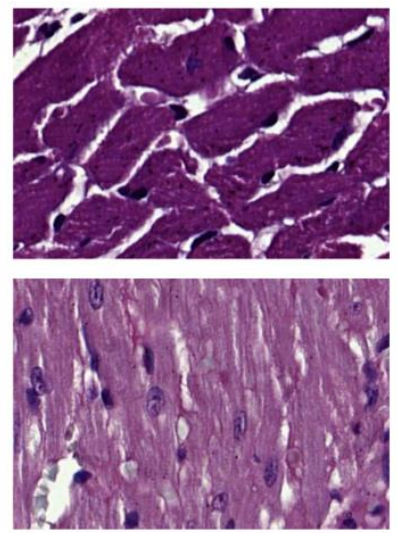

HLP

Figure 1. A - Photomicrography stained with hematoxylin/eosin representative of the left ventricle showing the diameter of the cardiomyocytes. B - Photomicrography stained with picrosirius red showing the distribution of interstitial collagen (marked in red by the stain) in the left ventricular myocardium of the mice. $\mathrm{C}-$ standard diet; $\mathrm{CP}$ - standard diet and dry Passiflora incarnata L. leaf extract; HL - high-fat diet; HLP - high-fat diet and dry Passiflora incarnata L. leaf extract. 


\section{DISCUSSION}

In the present study, we verified that the administration of Passiflora incarnata L. extract influenced the lipid profile of mice from the HLP group, preventing the decrease of HDLc and the increase of TG and TC. The last can be attributed to the presence of flavonoids in the extract. These flavonoids inhibit the enzyme responsible for the biosynthesis of cholesterol by Hydroxymethylglutaryl CoA reductase, as well as the lipogenic enzyme glucose-6-phosphate dehydrogenase and malic enzyme ${ }^{24,25}$.

The mice from group HL presented LVH similar to those of studies developed in our laboratory, demonstrating that LDL-/- mice fed high-fat diet developed LVH and atherosclerosis due to the inflammatory process caused by severe dyslipidemia, associated to the decrease of the bioavailability of nitric oxide and of the serum levels of HDL and its antioxidant and anti-inflammatory functions ${ }^{3,26-29}$. Furthermore, HL mice presented resistance to insulin, with hyperinsulinemia associated with the increase in serum levels of enzymes AP, AST, and ALT.

Dyslipidemia and insulin are essential factors for the development of left ventricular hypertrophy ${ }^{30}$. Hypercholesterolemia can act in $\mathrm{K}_{\text {ATP }}$ channels of the myocardium, altering its function and expression, presenting as a trigger for cardiac hypertrophy ${ }^{31,32}$. Insulin can cause the biosynthesis of myocardiac proteins and, directly or indirectly, cardiac hypertrophy ${ }^{33}$. Therefore, the decrease of total cholesterol and triglycerides, associated with the decline in insulin levels, contribute to the prevention of LVH in mice from group HLP. Passiflora incarnata L. prevented LVH, resistance to insulin, an increase of CRP and oxidative stress. However, the lower occurrence of oxidative stress has prevented the decrease of liver HDL with a consequent increase in the levels of HDLc, hindering the development of LVH in the animals used for this study, due to its antioxidant and anti-inflammatory functions ${ }^{34,35}$.

The mice that received high-fat diet and dry Passiflora incarnata L. extract (HLP), when compared to the HL group, presented an increase in the levels of HDLc and a decrease in TG and insulin, which are predicting factors for the metabolic syndrome ${ }^{36,37}$. A reduction in CRP, inflammation biomarker commonly found in high levels in the metabolic syndrome, was also observed ${ }^{38}$, contributing with a reduction of the risk of cardiovascular diseases such as LVH.

Notably, the mice that received a high-fat diet with Passiflora incarnata L. demonstrated a significant reduction in carbonyl proteins and lipid peroxidation, both considered oxidative stress markers ${ }^{21 ; 23}$. The flavonoids present in Passiflora incarnata $\mathrm{L}$., such as vitexin and isovitexin ${ }^{39}$, present antioxidant activity ${ }^{40}$, which may have contributed to the reduction of the oxidative stress markers for group HLP. Flavonoids present antioxidant activity by eliminating free radicals, employing the metal-chelating property, suppressing the enzymes involved in the synthesis of free radicals and by stimulating the antioxidant enzymes ${ }^{41}$. The use of antioxidants is a strategy to prevent hepatic oxidative stress and, consequently, the hepatic diseases originated from oxidative stress ${ }^{42}$.

\section{CONCLUSIONS}

The dry Passiflora incarnata L. extract presented antioxidant effect, preventing cardiac and hepatic diseases related to oxidative stress, and can be indicated as an aid for the treatment of diseases caused by oxidative stress derived of disturbances in lipid metabolism. 


\section{ACKNOWLEDGEMENTS}

We thank the Instituto Federal de Educação, Ciência e Tecnologia do Sul de Minas (Brazil) and Universidade José do Rosário Vellano (Brazil) for the support.

\section{REFERENCES}

1. World Health Organization (WHO). Top 10 causes of death: leading causes of death. 2017; Acessed in 19 Jul. 2017; Available from: http://www.who.int/mediacentre/factsheets/fs310/en/.

2. Adam M, Cohen MD, Daniel J, Rader MD. Dyslipidemia. Curr Treat Options Cardiovasc Med. 2001; 3: 347-357.

3. Garcia JAD, Santos L, Moura AL, Ricardo KFS, Wanschel ACBA, Shishido SM, et al. SNitroso-NAcetylcysteine (SNAC) Prevents Myocardial Alterations in Hypercholesterolemic LDL Receptor Knockout Mice by Antiinflammatory Action. J Cardiovasc Pharmacol. 2008; 51(1):78-85.

4. Madamanchi NR, Vendrov A, Runge MS. Oxidative stress and vascular disease. Arterioscler Thromb Vasc Biol. 2005; 25(4):29-38.

5. Balkan J, Oztezcan S, Aykac-Toker G, Uysel M. Effects of added dietary taurine on erythrocyte lipids and oxidative stress in rabbits fed a high cholesterol diet. Biosci Biotechnol Biochem. 2002; 66(12):2701- 2705.

6. Abuohashish HM, Aleisa AM, Ahmed MM, Alkhamees OA, Al-Rejaie SS, Alroujayee AS. Ameliorative effects of rutin and ascorbic acid combination on hypercholesterolemiainduced hepatotoxicity in female rats. Afr J Pharm Pharmacol. 2013; 7(6):280-288.

7. Cichoż-Lach H, Michalak A. Oxidative stress as a crucial factor in liver diseases. World $J$ Gastroenterol. 2014; 7(20):8082-8091.

8. Faludi AA, Izar MCO, Saraiva JFK, Chacra APM, Bianco HT, Afiune Neto A, et al. Atualização da Diretriz Brasileira de Dislipidemias e Prevenção da Aterosclerose - 2017. Arq Bras Cardiol. 2017; 109(2)supl.1:1-76.

9. Pizziolo VR, Brasileiro BG, Oliveira TT, Nagem TJ. Plantas com possível atividade hipolipidêmica: uma revisão bibliográfica de livros editados no Brasil entre 1998 e 2008. Rev Bras Plantas Med. 2011; 13(1): 98109.

10. Moll, MCN. Antihiperlipemiantes de origen vegetal. Rev Fitoter. 2006; 6:11-26.

11. Gonçalves MCR, Diniz MFFM, Borba JDC, Nunes XP, Barbosa-Filho JM. Berinjela (Solanum melongena L.) - mito ou realidade no combate as dislipidemias? Rev Bras Farmacogn. 2006; 16(2):252-257.

12. Dhawan K, Kumar R, Kumar S, Sharma A. Correct Identification of Passiflora incarnate Linn., a Promising Herbal Anxiolytic and Sedative. J Med Food. 2001; 4(3):137-144.

13. Dhawan K, Kumar S, Sharma A. Suppression of alcohol-cessation-oriented hyper-anxiety by the benzoflavone moiety of Passiflora incarnata Linn. in mice. J Ethnopharmacol. 2002; 81:239-244.

14. Dhawan K, Kumar S, Sharma A. Anti-anxiety studies on extracts of Passiflora incarnata Linn. J Ethnopharmacol. 2001a; 78:165-170.

15. Dhawan K, Kumar S, Sharma A. Anxiolytic activity of aerial and underground parts of Passiflora incarnata. Fitoterapia. 2001b; 72:922-926.

16. Wohlmuth H, Penman KG, Pearson T, Lehmann RP. Pharmacognosy and chemotypes of Passionflower (Passiflora incarnata L.). Biol Pharm Bull. 2010; 33(6):1015-1018.

17. Hedrick CC, Castellani LW, Wong H, Lusis AJ. In vivo interactions of apoA-II, apoA-I, and hepatic lipase contributing to HDL structure and antiatherogenic functions. J Lipid Res. 2001; 42(4):563-570.

18. Junqueira LC, Bignolas G, Brentani RR. Picrosirius staining plus polarization microscopy, a specific method for collagen detection in tissue sections. Histochem J. 1979; 11(4): 447-455. 
19. Shirani J, Pick R, Roberts WC, Maron BJ. Morphology and significance of the left ventricular collagen network in young patients with hypertrophic cardiomyopathy and sudden cardiac death. J Am Coll Card. 2000; 35(1):36-44.

20. Armstrong AT, Binkley PF, Baker PB, Myerowitz PD, Leier CV. Quantitative investigation of cardiomyocyte hypertrophy and myocardial fibrosis over 6 years after cardiac transplantation. J Am Coll Cardiol. 1998; 32(3):704-710.

21. Winterbourn CC, Gutteridge JM, Halliwell B. Doxorubicin-dependent lipid peroxidation at low partial pressures of $\mathrm{O}_{2}$. J Free Radic Biol Med. 1985; 1(1):43-49.

22. Bradford MM. A rapid and sensitive method for the quantitation of microgram quantities of protein utilizing the principle of protein-dye binding. Anal Biochem. 1976; 72:248-254.

23. Punchard NA, Kelly FJIRL. Free Radicals: A Practical Approach. Oxford: Oxford University Press; 1996.

24. Anila L, Vijayalakshmi NR. Flanonoids from Emblica officinalis and Mangifera indica effectiveness for dyslipidemia. J Ethnopharmacol. 2002; 79(1):81-87.

25. Jung UJ, Lee MK, Park YB, Kang MA, Choi MS. Effect of citrus flavonoids on lipid metabolism and glucoseregulating enzyme mRNA levels in type-2 diabetic mice. Int $J$ Biochem Cell Biol. 2006; 38(7):1134-1145.

26. Krieger MH, Santos KFR, Shishido SM, Wanschel ACBA, Estrela HFG, Santos L, et al. Antiatherogenic effects of S-nitroso-N-acetylcysteine in hypercholesterolemic LDL receptor knockout mice. Nitric Oxide. 2006; 14(1):12-20.

27. Garcia JAD, Lima CC, Messora LB, Cruz AF, Marques APS, Simão TP, et al. Efeito antiinflamatório da lipoproteína de alta densidade no sistema cardiovascular de camundongos hiperlipidêmicos. Rev Port Cardiol. 2011; 30(10):763-774.

28. Silva DB, Miranda AP, Silva DB, D'Angelo LR, Rosa BB, Soares EA, et al. Propolis and swimming in the prevention of atherogenesis and left ventricular hypertrophy in hypercholesterolemic mice. Braz J Biol. 2015; 75(2):414-422.

29. Santos L, Davel AP, Almeida TIR, Almeida MR, Soares EA, Fernandes GJM, et al. Soy milk versus simvastatin for preventing atherosclerosis and left ventricle remodeling in LDL receptor knockout mice. Braz J Med Biol Res. 2017; 50(3): e5854.

30. Garcia JAD, Incerpi EK. Factors and mechanisms involved in left ventricular hypertrophy and the antihypertrophic role of nitric oxide. Arq Bras Cardiol. 2008; 90(6):443-450.

31. Ueda Y, Kitakaze M, Komamura K, Minamino T, Asanuma H, Sato H, et al. Pravastatin restored the infarct size-limiting effect of ischemic preconditioning blunted by hypercholesterolemia in the rabbit model of myocardial infarction. J Am Coll Cardiol. 1999; 34(7):2120-2125.

32. Genda S, Miura T, Miki T, Ichikawa Y, Shimamoto K. K(ATP) channel opening is an endogenous mechanism of protection against the no-reflow phenomenon but its function is compromised by hypercholesterolemia. J Am Coll Cardiol. 2002; 40(7):1339-1346.

33. Samuelsson AM, Bollano E, Mobini R, Larsson BM, Omerovic E, Fu M, et al. Hyperinsulinemia: Effect on Cardiac Mass/Function, Angiotensin II Receptor Expression, and Insulin Signaling Pathways. Am J Physiol Heart Circ Physiol. 2006; 291(2):H787-796.

34. Christison J, Karjalainen A, Brauman J, Bygrave F, Stocker R. Rapid reduction and removal of HDL- but not LDL associated cholesteryl ester hydroperoxides by rat liver perfused in situ. Biochem J. 1996; 314(3):739-742.

35. Holvoet P. Relations between metabolic syndrome, oxidative stress and inflammation and cardiovascular disease. Verh K Acad Geneeskd Belg. 2008; 70(3):193-219.

36. Alberti FGMM, Zimmet PZ. For the WHO Consultation. Definition, diagnosis and classification of diabetes mellitus and its complications. Part 1: Diagnosis and classification of diabetes mellitus, provisional report of a WHO consultation. Diabet Med. 1998; 15(7):539553.

37. JAMA. Expert Panel on Detection, Evaluation and Treatment of High Blood Cholesterol in Adults. Executive summary of the Third Report of the National Cholesterol Education Program (NCEP) Expert Panel on Detection, Evaluation and Treatment of High Cholesterol. JAMA. 2001; 285(19):2486-2497.

38. Ridker PM, Hennekens CH, Buring JE, Rifai N. Proteína C-reativa e outros marcadores de inflamação na predição de doenças cardiovasculares em mulheres. N Engl J Med. 2000; 342:836-843. 
39. He M, Min JW, Kong WL, He XH, Li JX, Peng BW. A review on the pharmacological effects of vitexin and isovitexin. Fitoterapia. 2016; 115:74-85.

40. Marroquín MN, Cruz SM, Cáceres, A. Antioxidant activity and phenolic compounds in three species of Passifloraceae (Passiflora edulis, P. incarnata, P. ligularis) from Guatemala. Acta Hortic. 2012; 964:93-98.

41. Procházková D, Bousová I, Wilhelmová N. Antioxidant and prooxidant properties of flavonoids. Fitoterapia. 2011;82(4):513-523.

42. Li S, Tan HY, Wang N, Zhang ZJ, Lao L, Wong CW. The Role of Oxidative Stress and Antioxidants in Liver Diseases. Int J Mol Sci. 2015; 16(11):26087-26124.

Received: March 20, 2018; Accepted: September 08, 2018 